\title{
ESSAYS
}

\section{THE UNIVERSITY OF PENNSYLVANIA LAW REVIEW: 150 YEARS OF HISTORY}

\author{
EDWIN J. GREENLEE ${ }^{\dagger}$
}

The University of Pennsylvania Law Review' is one of the nation's oldest law reviews and the oldest continuously published legal periodical in the United States. ${ }^{2}$ The predecessor publication of the Law Review, the American Law Register, was published by members of the Philadelphia Bar beginning in 1852. ${ }^{3}$ As the Penn Law Review marks its 150th anniversary, this Essay reviews its history and details a few of the many significant signposts of the previous 150 years. In addition, this Essay looks at a few representative articles published in the Law Review and some of the personalities who made the University of Pennsylvania Law Review the significant publication that it is today.

The birth of the Penn Law Review proper-that is, as a studentedited legal publication closely affiliated with a major law school-was the result of reforms in legal education in the late-nineteenth and early-twentieth centuries. The Penn Law Review shares a common history with a number of other law reviews that were established during the same time period, such as those at Harvard, Columbia, and Yale law schools. ${ }^{4}$

\footnotetext{
${ }^{\dagger}$ M.S., J.D., Ph.D., Acting Co-Director/Associate Director for Public Services, Biddle Law Library, University of Pennsylvania Law School. I would like to express my thanks to Paul Bond and Lindsay Goldman for their editorial assistance and to Laura T. Spadanuta and Micah Toomey for their research assistance.

1 This publication will be referred to as the "Penn Law Review" or the "Law Review" throughout this piece.

${ }^{2}$ Michael L. Closen \& Robert J. Dzielak, The History and Influence of the Law Review Institution, 30 AKRON L. REV. 15, 32, 35 (1996). For an acknowledgement of the historical priority of the University of Pennsylvania Law Review, see Barbara H. Cane, Comment, The Role of the Law Review in Legal Education, 31 J. LEGAL EDUC. 215, 215 (1981).

Joseph P. Flanagan, Jr., Volume 100, 100 U. PA. L. REV. 69, 69 (1951).

4 See Michael I. Swygert \& Jon W. Bruce, The Historical Origins, Founding and Early Development of Student-Edited Law Reviews, 36 HASTINGS L.J. 739, 778-91 (1985) (describing the parallel development and common features of the first student-edited law reviews).
} 
The Law Review has faced many of the same challenges that have been presented to legal education and the legal profession itself. From its inception until today, the Law Review has had to strike a balance between the pragmatic orientation that legal practitioners require and the more academic, scholarly approach that first developed in legal publishing during the advent of the twentieth century. ${ }^{5}$ The Law Review has had to find ways to finance and staff a sizeable publication even during periods of great fluctuation in the University of Pennsylvania Law School's student population, such as those occasioned by the First and Second World Wars. The Law Review, no less than the Law School, ${ }^{6}$ has had to work to foster racial, ethnic, and gender equity and access to opportunity. Surmounting these challenges, the Law Review has offered, and continues to offer, a venue for legal scholars to articulate, develop, and refine their contributions to legal discourse.

Over the past 150 years, the ideologies and bases of legal scholarship have changed dramatically, as has the identity of legal scholars. Legal realism, progressivism, and, more recently, multidisciplinary approaches such as law and economics have become new centers of interest. ${ }^{7}$ Voices from and for the margin have developed critical legal studies, critical race theory, and feminist theory, as well as varieties of postmodernism that owe their impetus to continental scholars such as Michel Foucault, Jacques Derrida, and Jürgen Habermas. ${ }^{8}$

All of these approaches to legal scholarship have been represented by leading 'articles in the Penn Law Review. Additionally, articles in the Law Review have captured seminal historical, social, and legal moments in nineteenth- and twentieth-century American history, such as the passage of the Nineteenth Amendment, which extended suffrage to women; ${ }^{9}$ the lawlessness of the First and Second World

${ }^{5}$ See id. at 790 (explaining that the first student-edited law reviews were designed "to facilitate academic scholarship").

${ }^{6}$ The University of Pennsylvania Law School will be referred to as the "Law School" or "Penn Law" throughout this Essay.

${ }^{7}$ For an examination of changing interests in legal scholarship from the midnineteenth to the mid-twentieth century, see generally MORTON J. HORWITZ, THE. TRANSFORMATION OF AMERICAN LAW 1870-1960, at 3-7 (1992).

${ }^{8}$ For a discussion of historical trends in law review literature, and a suggestion that law reviews recuse themselves from nondoctrinal scholarship, see generally Richard A. Posner, The Future of the Student-Edited Law Review, 47 STAN. L. REV. 1131, 1133 (1995).

${ }^{9}$ See, e.g., William J. Marbury, The Proposed Woman Suffrage Amendment and the Amending Power, 65 U. PA. L. REV. 403, 404 (1917) (questioning whether the Nineteenth Amendment would be void because of limitations on the amending power); 
Wars and our attempts to restore lawful administration afterward; ${ }^{10}$ the rise of the security state during the Cold War; ${ }^{11}$ the struggle for civil rights; ${ }^{12}$ and the protests against the conflict in the Vietnam. ${ }^{13}$ Other historical moments captured in the history of the Law Review include the burst of technology in the late-twentieth century, including the development of computer technology and the Internet. ${ }^{14}$

The contents of the Law Review have included lead articles, case comments, notes authored by the Law Review's staff, book reviews, and asides. ${ }^{15}$ Special issues of the Law Review have honored important fig-

Recent Case, Jury Service-Eligibility of Women, 69 U. PA. L. REv. 386 (1921) (discussing whether granting suffrage to women would qualify them for jury service).

${ }^{10}$ See, e.g., Randolph Greenfield Adams, Growth of Belligerent Rights over Neutral Trade, 68 U. PA. L. REV. 20, 21-22 (1919) (discussing the conflict between the right of neutral states, during a period of war, to continue commerce with all belligerent parties and the right of belligerent parties to prevent neutral parties from supplying to an enemy state goods that could be used for military purposes); Note, The Legal Limits of Personal Liberties in Times of War, 90 U. PA. L. REv. 598, 598 (1942) (noting that during the prosecution of war, the federal government may take "repressive measures which would be deemed dictatorial in times of peace," and inquiring into "the Constitutional authority upon which [such measures] may be invoked" and "their effect upon the liberties guaranteed by the Bill of Rights").

${ }_{11}$ See, e.g., Louis Henkin, The Right to Know and the Duty to Withhold: The Case of the Pentagon Papers, 120 U. PA. L. REv. 271, 275 (1971) (describing governmental secrecy as "at best a necessary evil"); Shirley M. Hufstedler, Invisible Searches for Intangible Things: Regulation of Govermment Information Gathering, 127 U. PA. L. REv. 1483, 1516-23 (1979) (observing a need to strike a balance between the public interest in maintaining a secure state and the societal interest in preserving individual privacy).

${ }_{12}$ For example, Penn Law Review published two defenses of Shelley v. Kraemer, 334 U.S. 1 (1948), which declared court enforcement of racially restrictive covenants to be state action violative of the Fourteenth Amendment's Due Process Clause, against vociferous attacks. Louis Henkin, Shelley v. Kraemer: Notes for a Revised Opinion, 110 U. PA. L. REV. 473, 500-05 (1962); Louis H. Pollak, Racial Discrimination and Judicial Integrity: A Reply to Professor Wechsler, 108 U. PA. L. REV. 1, 6-18 (1959).

${ }^{13}$ See, e.g., Raoul Berger, War-Making by the President, 121 U. PA. L. REV. 29, 45 (1972) (questioning whether the Javits Bill was an unconstitutional delegation of authority to the President to use the armed forces); Martha A. Field, Problems of Proof in Conscientious Objector Cases, 120 U. PA. L. REv. 870, 933-50 (1972) (proposing changes in the nation's draft laws, particularly those with respect to conscientious objector claims); William Van Alstyne, Congress, the President, and the Power to Declare War: A Requiem for Vietnam, 121 U. PA. L. REv. 1, 27-28 (1972) (suggesting that the war in Vietnam became unconstitutional after the Tonkin Gulf Resolution was repealed).

${ }^{14}$ See, e.g., Seth F. Kreimer, Technologies of Protest: Insurgent Social Movements and the First Amendment in the Era of the Internet, 150 U. PA. L. REV. 119, 170 (exploring the role of the Internet in "facilitating the emergence of insurgent social movements"); Gary R. Ignatin, Comment, Let the Hackers Hack: Allowing the Reverse Engineering of Copyrighted Computer Programs to Achieve Compatibility, 140 U. PA. L. REV. 1999, 2000 (1992) (arguing for less stringent copyright protection for computer software).

${ }_{15}$ "Once every few years, the editorial board of the University of Pennsylvania Law Review goes on a frolic and detour. The product of such an escapade is commonly la- 
ures in the legal community such as the Honorable A. Leon Higginbotham. ${ }^{16}$ On occasion, the Law Review has published as symposium issues the papers resulting from conferences such as one on metropolitan regionalism, issued in $1957 .{ }^{17}$ Part I of this Essay highlights a few representative pieces from the myriad published in the Law $R e-$ view's first 150 years.

The Penn Law Review has had an impact on a number of levels. As a key institution at Penn Law, one of the nation's premier law schools, the Law Review has influenced the development of the Law School's curriculum. ${ }^{18}$ In addition, membership on Law Review has shaped the education and careers of many Penn Law students. Part II will explore a few of the personalities connected with the Law Review over the years.

Beyond the particular editors involved, the Penn Law Review has been a major influence on the development of American law, as indicated by bibliometric and analytical research, which examines citations to law review articles to assess their impact on legal scholarship and judicial decision making. These citation studies are the subject of Part III of this Essay.

\section{LAW REVIEW SCHOLARSHIP IN CONTEXT}

Examining the 150 years of substantive content of the University of Pennsylvania Law Review reveals that some writers explored rather narrow, technical legal issues. Others engaged the pressing social and legal issues of the day, using intellectual tools extracted from within the world of legal scholarship as well as from the broader field of social science.

The history of the University of Pennsylvania Law Review begins with the 1852 publication of the American Law Register during a turbulent

beled an 'Aside,' the most famous of which is The Common Law Origins of the Infield Fly Rule," 123 U. PA. L. REV. 1474 (1975), and the most recent of which is Challenging Law Review Dominance, 149 U. PA. L. REV. 1601 (2001). Ex Ante, 5 GreEN BAG 2D 1, 3 (2001).

${ }^{16}$ Dedication, A. Leon Higginbotham, $J r .:$ The Man, 142 U. PA. L. REV. 511, 511 (presenting tributes by Edward R. Becker, Guido Calabresi, Anne Whatley Chain, John P. Frank, Ronald K. Noble, Louis H. Pollak, and Bernard Wolfman).

${ }^{17}$ See Symposium, Metropolitan Regionalism: Developing Governmental Concepts, $105 \mathrm{U}$. PA. L. REV. 439 (1957) (exploring metropolitan characteristics, identifying problems unique to cities, and suggesting how one might recognize the group values of any given metropolitan area).

${ }^{18}$ This is both the author's personal observation and is suggested generally by ideas in Swygert \& Bruce, supra note 4, at 779. 
period of American history that would see the election of Abraham Lincoln and the onset of the Civil War. ${ }^{19}$ The nation was becoming ever more conscious of the tragedy of slavery in 1852, the year in which Harriet Beecher Stowe published Uncle Tom's Cabin. ${ }^{20}$ In the years following the Register's debut, America experienced the destruction of the Civil War and the ensuing period of national reconstruction. ${ }^{21}$ While many articles in the American Law Register had a narrow, technical focus, several addressed the social and political issues of the times. $^{22}$

The inaugural volume of the American Law Register offered a format the editors retained for most of the first fifty years of publication, prior to the time that it became a publication of the Law School. ${ }^{29}$ Each volume included leading articles by legal practitioners, judges, or law professors, along with summaries of recent American cases and foreign judicial decisions. ${ }^{24}$ The Register also provided short book reviews and tributes to notable members of the legal profession. Substantive articles focused on doctrinal topics such as chancery court jurisdiction, voluntary assignments of chattel property, and the rights and liabilities of parents vis-à-vis their minor children.

Since its inception, the University of Pennsylvania Law Review and its predecessor publications have attempted to balance service to the legal profession with the advancement of legal scholarship. In its first

19 ENCYClopedia OF AMERICAN History 240-57 (Richard B. Morris \& Jeffrey B. Morris eds., 7th ed. 1996).

${ }^{20} I d$. at 240.

21 Id, at 257-84.

${ }^{22}$ See, e.g., Martial Law, 9 AM. L. REG. 498, 498 (1861) (discussing the relationship between the military and its partners in the state during periods of national crisis and, more specifically, the use of martial law); W.A. Maury, The Late Civil War, 23 AM. L. REG. 129, 132 (1875) (discussing generally the impact of the Civil War on jurisdiction and civil remedies and arguing that "so soon as the state of things called civil war came into existence the powers of the government of the United States were . . . suspended throughout the states seceded" and that government "wholly destitute of power or discretion in the premises had no alternative but to observe the rules of conduct prescribed by the jus gentium [international law] for the government of belligerents"); The Power of the President to Grant a General Pardon or Amnesty for Offenses Against the United States, 17 AM. L. REG. 513, 513-14 (1869) (discussing President Johnson's Dec. 25, 1868, proclamation granting pardon and amnesty to those whose actions during the Civil War were treasonous).

${ }^{23}$ For a general discussion of the "standardized format" of American law reviews in the late-nineteenth and early-twentieth centuries, see John Jay McKelvey, The Law School Review: 1887-1937, 50 HARV. L. REV. 868 (1937).

${ }^{24}$ For examples of summaries of decisions from Great Britain and France, see Recent English Cases, 1 AM. L. REG. 37 (1852); and Recent French Decisions, 1 AM. L. REG. 42 (1852). 
life as the American Law Register, the Law Review was published, written, and edited by practicing lawyers for practicing lawyers. The first editors in 1852 were Asa Fish and Henry Wharton, members of the Pennsylvania Bar. ${ }^{25}$ During the mid- and late-nineteenth century, the publisher of the American Law Register selected judges, practicing attorneys, and law faculty to serve as editors. ${ }^{26}$ In 1892, two Philadelphia attorneys, George Wharton Pepper and William Draper Lewis became the sole editors. ${ }^{27}$ They published the periodical under the name American Law Register and Review. ${ }^{28}$

In 1895, Lewis became Dean of the University of Pennsylvania Law School, at which time he succeeded in having the Law School take over the production of the publication under the direction of a board of student editors. ${ }^{29}$ The 1896 Volume was the first to be published under a group of student editors. ${ }^{30}$ In 1908, the name of the periodical was changed from the American Law Register and Review to the University of Pennsylvania Law Review and American Law Register. ${ }^{\text {gl }}$ The publication kept that name until 1945, when it was given its present name, the University of Pennsylvania Law Review. ${ }^{32}$

While the Law Review initially published articles of primary interest to legal practitioners, in time it would adopt a more academic bent. In its first half-century, the American Law Register addressed a number of topics typically characterized as "doctrinal." Doctrinal articles focus on legal rules in traditional areas such as contracts or torts. These articles are distinguished from articles that are more concerned with law's social, historical, political, or philosophical context.

The time during which the Law School took over publication of the American Law Register was an age of great technological change in America. Steam energy and electricity were introduced into the country's manufacturing industries and transportation systems; there was a great change in national transportation, marked by the expansion of the country's railroads. ${ }^{39}$ There were, in addition, demographic changes brought about by a new period of immigration from

${ }^{25}$ Flanagan, supra note 3, at 69; see also Appendix B.

${ }^{26}$ Flanagan, supra note 3, at 69.

${ }^{27}$ Id.; see also Appendix B.

${ }^{28}$ Flanagan, supra note 3 , at 69 .

${ }^{29}$ Id.

${ }^{30}$ Id.; see also Appendix A.

31 UnIV. OF PA. LAw SCH., THE RECORD 62 (1923).

${ }^{32}$ Flanagan, supra note 3, at 69.

33 HOWARD ZinN, A PEOPLE's History OF THE UNITED STATES 247 (1980). 
Europe. ${ }^{34}$ It was also a time of economic instability and labor unrest. While many of the articles published by the Law Review at this time addressed narrow, technical legal issues, a few reflected their historical context. ${ }^{35}$

The University of Pennsylvania Law Review proper was established in 1896. At about the same time, several other law reviews were being founded at America's premier law schools. The Harvard Law Review began publication in 1887, followed by the Yale Law Journal in $18911^{36}$ Law reviews were initiated at the law schools at Columbia in 1901 and Michigan in $1902 .^{37}$

The late-nineteenth-century experiences of the University of Pennsylvania Law School parallel the experiences of a number of the other law schools that began publishing law reviews at roughly the same time. ${ }^{38}$ In the late 1890 s, law reviews adopted the form we know today. The institution of the Law Review is intimately tied to the model of legal education based upon the study of appellate cases, called the case method, espoused by Christopher Columbus Langdell at Harvard." "Students who excelled in the classroom wrote for the Law Review, where they typically applied this scientific analysis [the case method] to a recently decided case." ${ }^{40}$ Thus, the tools used for achievement in the classroom setting under the case method were the same tools used in a student's work on Law Review.

In the early-twentieth century, the Law Review published eight issues per year. ${ }^{41}$ In 1918, amid the worsening economic conditions in the country at the conclusion of the First World War, financial concerns led the board to reduce the number of issues to four per year. ${ }^{42}$ Beginning with Volume 119, published from 1970 to 1971, the Law

${ }^{34}$ Id. at 259.

${ }^{95}$ See, e.g., William Draper Lewis, Strikes and Courts of Equity, 46 AM. L. REG. 1, 2-3 (1898) (discussing the issue of criminal contempt coupled with the use of the injunction as used against assemblies of striking workers); Richard A. McMurtle, The Legal Rights and Duties of Employers and Employed as Affecting the Interests of the Public, $41 \mathrm{AM}$. L. REG. 421, 426 (1938) (discussing a Pennsylvania statute that allowed for the prosecution of individuals or groups who hinder "any one who desires to labor for their employer").

${ }^{36}$ Swygert \& Bruce, supra note 4 , at $773,779$.

${ }^{37} I d$. at 779 .

${ }^{38} \mathrm{Id}$.

${ }^{39}$ Cane, supra note 2, at 216-17.

${ }^{40} I d$. at 217.

41 UNIV. OF PA. LAW SCH., supra note 31, at 62.

${ }^{42} I d$. 
Review went to six issues. ${ }^{43}$

In 1923, the Law Review board sought to bring about closer cooperation with "practicing attorneys and judges so that more of the latter [could] become contributors of articles, [and thus] the Law Review [would] be in a position to render to the legal profession a service second to that of no other law school publication." still evidences a commitment to the practicing bar and bench and expresses the desire to reach beyond an academic audience.

During the latter part of the nineteenth century and the early part of the twentieth century, as the country faced such concerns as women's suffrage, the First World War, and the increasing ethnic and religious diversity of the population, the authors writing in the Law Review addressed these issues along with other, more narrowly focused topics. In its 1892 Volume the Register featured an article by James T. Ringgold examining the Sunday laws in the United States. ${ }^{45}$ This article was published at a time when there was a much stronger link between religion-Christianity in particular-and civil society in America. $^{46}$ The Sunday laws challenged the separation of church and state by prescribing the use of governmental power to close places of business and entertainment on Sunday, ${ }^{47}$ the Sabbath observed by most Christians, and to prevent individuals and groups from engaging in activities that would "disturb" the Sabbath. ${ }^{48}$

Ringgold discussed the various rationales given for Sunday laws, which tend to ignore or obfuscate the fact that the statutes actually forced all citizens to observe Christian obligations. ${ }^{49}$ One example of a pretextual rationale for Sunday laws was the idea that a mandatory day of rest was necessary to maintain the general health of the population. ${ }^{50}$ While these statutes were considered constitutional in the early

43 At the time of this change in the frequency of the publication of the Law Review, Bernard Wolfman became Dean of the Law School, succeeding Jefferson Fordham. Derek Davis, "A Living Science and a Present Art": A History of the University of Pennsylvania Law School 188-89 (2000) (unpublished manuscript, on file with author).

${ }^{44}$ Id.

45 James T. Ringgold, Sunday Laws in the United States, 40 AM. L. REG. 723 (1892).

46 See, e.g., Jonathan D. SaRna \& David G. Dalin, Religion and State in the AMERICAN JEWISH EXPERIENCE 9-12 (1997) ("[A]ll of the states enacted Sunday laws of some form or other in the nineteenth century, and over the years religious leaders mounted recurrent campaigns to revitalize Sabbath observance, both by enacting new laws and by promoting enforcement of those already on the books.").

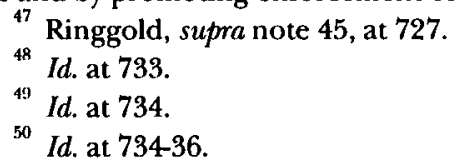


twentieth century, ${ }^{51}$ clearly they raised challenges to the notion of the separation of church and state, especially since the country was becoming ever more religiously diverse.

During the second decade of the twentieth century, America's attention was drawn to American women and the right to vote. The Law Review published an article by William J. Marbury who argued against the "proposed woman suffrage amendment." ${ }^{\text {"2 }}$ The author attacked the amendment on procedural grounds, arguing that the way in which the amendment was being adopted violated the proper methods that can be used to amend the Constitution. Marbury acknowledged the legitimacy of amendment of the U.S. Constitution by means of a national constitutional convention or by conventions held in each of the states. ${ }^{53}$ Marbury found that the method by which the women's suffrage amendment was to be adopted, which called for ratification by three-quarters of the legislatures of the various states, was invalid procedurally. ${ }^{54}$

Arguing from a states' rights perspective, Marbury wrote that this amendment would damage "the right of a State to determine for itself who shall constitute its electorate" and that this right of the state to establish its own electorate is "essential to the existence of a State." Thus, three-quarters of the states, by the process of constitutional amendment proposed in this instance, would "restrain at least or hamper in its exercise one of the functions essential to the very existence of a State within the meaning of the Constitution, and [was] therefore void." frage amendment be approved it would not withstand a constitutional challenge in the Supreme Court. ${ }^{57}$

Volume 69 of the Law Review, published in 1920 and 1921, contained articles on traditional subjects, such as an article on torts by Francis $H$. Bohlen that explored the duties that landowners have to invitees of their premises. ${ }^{58}$ At the time he wrote this article, Bohlen

${ }^{51}$ Id. at 723 .

${ }^{52}$ William J. Marbury, The Proposed Woman Suffrage Amendment and the Amending Power, 65 U. PA. L. REV. 403, 404 (1917).

${ }^{53}$ Id. at $405-06$.

${ }^{54}$ Id. at 405-07.

${ }^{55} I d$. at 410 (internal quotation marks omitted).

${ }^{56}$ Id.

${ }^{57}$ Id. at 420.

${ }^{58}$ Francis H. Bohlen, The Duty of a Landowner Toward Those Entering His Premises of Their Own Right, 69 U. PA. L. REv. 237 (1921). 
was Biddle Professor of Law at the Law School ${ }^{59}$ and, according to William Draper Lewis, was "the outstanding authority on the Law of Torts in the United States."

This Volume also contained articles particular to Pennsylvania. One example is Alex Simpson's article on the definition of "residence" in Pennsylvania for the purpose of voting. ${ }^{61}$ Simpson was one of the founders of the Pennsylvania Bar Association and served as its president and chairman of its Committee on Law Reform for more than twenty years. ${ }^{62}$ Simpson was appointed to the Pennsylvania Supreme Court in 1918. ${ }^{63}$ This feature of the Penn Law Review, publishing a few articles each year that were Pennsylvania specific, continued during much of the twentieth century. In keeping with the Law Review's tradition of including international perspectives, an article included in Volume 69 looked at legal changes in Latin America. ${ }^{64}$

During the 1920s and 1930s the United States saw a major economic depression and widespread economic suffering, labor unrest, and a large number of strikes. ${ }^{65}$ The American government began to look at social and economic pressures facing America and contemplated appropriate legal responses. Authors called for a more activist federal government during this time of dramatic technical and economic changes in American society. Women demanded an active role in American political life by means of the right to vote. In the 19241925 Volume of the Law Review, Margaret Center Klinglesmith authored an article dealing with the process of amending the federal constitution. $^{66}$ Klinglesmith was the first female law school librarian in the United States and, in 1916, received the first honorary LL.M. that the University of Pennsylvania granted to a woman. ${ }^{67}$ The context for this article was the period of federal constitutional amendment the country recently had undergone, particularly concerning the postCivil War (Thirteenth, Fourteenth, and Fifteenth) Amendments, an

${ }^{59}$ Davis, supra note 43 (manuscript at 58 ).

${ }^{60}$ William Draper Lewis, Francis Herman Bohlen, 91 U. PA. L. REV. 377, 377 (1943).

${ }^{61}$ Alex Simpson, Jr., What Constitutes a Voting Residence in Pennsylvania?, 69 U. PA. L. REV. 1 (1920).

${ }^{62}$ Legends of the Philadelphia Bar, PHILADELPHIA LAW., Winter 2002, at 56, 74.

Id.

${ }^{64}$ Thomas W. Palmer, A Study of the Mining Law of Chile, 69 U. PA. L. REV. 48 (1920)

Z5 ZINN, supra note 33, at 368-97.

${ }^{66}$ Margaret Center Klinglesmith, Amending the Constitution of the United States, $73 \mathrm{U}$.

PA. L. REV. 355 (1925).

${ }^{67}$ Davis, supra note 43 (manuscript at 175 ). 
amendment in the early twentieth century that authorized the collection of an income tax by the federal government (Sixteenth), the amendment authorizing Prohibition (Eighteenth), and the women's suffrage amendment that was proposed in July of 1919 and ratified in August of 1920 (Nineteenth) ${ }^{68}$ Klinglesmith noted a perhaps too eager desire to use the process of constitutional amendment rather than the normal legislative process. ${ }^{69}$ She stressed the gravity of amending the federal charter and urged caution in the use of the amendment power provided by Article V of the U.S. Constitution. ${ }^{70}$

Volume 75 of the Law Review, which was published in 1926 and 1927 , looked at equity jurisdiction in federal courts, ${ }^{71}$ British divorce law, ${ }^{72}$ and the use of torture in British law. ${ }^{73}$ Again, the Law Review emphasized traditional doctrinal issues at the same time that it examined historical and comparative legal matters.

In its Volume 85, published in 1936 and 1937, the Law Review published an article by Alpheus Thomas Mason, at that time a professor of politics at Princeton University, on President Franklin Roosevelt's proposal to "pack" the Supreme Court with up to fifteen additional Justices. ${ }^{74}$ President Roosevelt's action must be viewed in the context of rapid economic and social change in American society. Mason underscored the doctrinal tension between the President, who through his New Deal Program attempted to found the federal administrative state, and the Supreme Court, which invalidated much of the legislation associated with that program. ${ }^{75}$

Mason noted criticisms of the Court by former chief executives, by Congress, as well as by fellow jurists. ${ }^{76}$ Importantly, he also acknowledged that the Justices did not always use neutral principles of constitutional interpretation but, to a large extent, invalidated New Deal legislation on the basis of personal policy disagreements. ${ }^{77}$ Yet, guided by separation of powers arguments, Mason came out in favor of an in-

${ }^{68}$ Klinglesmith, supra note 66 , at $361-64$.

69 . at 365 .

Id. at 378-79.

${ }^{71}$ Robert von Moschzisker, Equity Jurisdiction in the Federal Courts, 75 U. PA. L. REV. 287 (1927).

${ }_{72}$ J.E.G. de Montmorency, Divorce Law in England, 75 U. PA. L. REV. 36 (1926).

${ }^{79}$ Ernest G. Black, Torture Under English Law, 75 U. PA. L. REV. 344 (1927).

74 Alpheus Thomas Mason, Politics and the Supreme Court: President Roosevelt's Proposal, 85 U. PA. L. REV. 659 (1937).

\footnotetext{
${ }^{75}$ Id. at 677 .

${ }^{76} \mathrm{Id}$. at 662-66.

${ }^{77} \mathrm{Id}$. at 664 .
} 
dependent judiciary.

Mason also reviewed earlier plans by American presidents to modify the membership of the Court to achieve the results that they wanted, ${ }^{78}$ as well as Congress's tampering with the Court in order to achieve policy goals. $^{79}$ Mason pointed out the problems with Roosevelt's plan for the Court and offered an alternative: "a constitutional amendment authorizing Congress . . . to over-ride by a two-thirds vote the judicial invalidation of an act of Congress." suggested legislation did not gain Congress's approval nor did the court-packing legislation championed by Roosevelt because both were distrusted by a majority of the American electorate.

Other articles published in Volume 85 included those involving doctrinal law, such as John S. Strahorn, Jr.'s article on the hearsay rule; ${ }^{81}$ international and foreign law, such as Charles Cheney Hyde's article on international cooperation for neutrality; ${ }^{82}$ and, once again, legal issues especially pertinent to Pennsylvania, such as Robert Brigham's piece on an aspect of Pennsylvania corporate law. ${ }^{83}$ Other articles in the same Volume evidenced a concern with broad issues pressing in contemporary American society, such as E.H. Foley, Jr.'s article on state financing of low-rent housing ${ }^{84}$ and Bernard Eskin's article on labor disputes.

After World War II, America experienced a period of extreme anti-Communist sentiment that was most prominently expressed by the leading anti-Communist crusader, Senator Joseph McCarthy. ${ }^{86}$ In this Cold War context, Murray L. Schwartz and James C.N. Paul published an article in Volume 107 of the Law Review on the federal censorship of foreign communist "propaganda" sent through the U.S. mail. ${ }^{87}$ At the time that he authored this article, Schwartz, a 1949

${ }^{78}$ Id. at 667 .

${ }^{79}$ Id. at 671 .

${ }^{80}$ Id. at 676.

${ }^{81}$ John S. Strahorn, Jr., A Reconsideration of the Hearsay Rule and Admissions, $85 \mathrm{U}$. PA. L. REV. 564 (1937).

${ }^{82}$ Charles Cheney Hyde, International Co-operation for Neutrality, 85 U. PA. L. REV. 344 (1937).

${ }^{83}$ Robert Brigham, Pennsylvania Rules Governing the Allocation of Receipts Derived by Trustees from Shares of Stock, 85 U. PA. L. REV. 358 (1937).

${ }^{84}$ E.H. Foley, Jr., Low-Rent Housing and State Financing, 85 U. PA. L. REV. 239 (1937).

${ }^{85}$ Bernard Eskin, The Legality of "Peaceful Coercion" in Labor Disputes, 85 U. PA. L. REV. 456 (1937).

${ }^{86}$ ZiNN, supra note 33, at 422-23, 426-28.

${ }^{87}$ Murray L. Schwartz \& James C.N. Paul, Foreign Communist Propaganda in the 
graduate of the Law School, was in private practice in Philadelphia. He later went on to become Professor of Law at UCLA. ${ }^{88}$ Paul, a 1951 University of Pennsylvania Law School graduate, was on the faculty of the Law School in the late 1950s and early 1960 s. $^{89}$

The Schwartz and Paul article is based upon an empirical study of mail censorship; the research was carried out under the auspices of the Institute of Legal Research at the University of Pennsylvania Law School. ${ }^{90}$ Mail censorship by the U.S. Postal Service grew out of the perceived need to censor Nazi and Communist propaganda during the 1940s. ${ }^{91}$ Censorship of materials from then-Communist nations such as China, the Soviet Union, and Poland continued. ${ }^{92}$ The justification for this later governmental action was the Korean War and midtwentieth-century congressional hearings on "the menace of . . . Red propaganda. ${ }^{, 93}$ These hearings included, in particular, those of the notorious House Un-American Activities Committee. ${ }^{94}$ The unbridled, excessive use of censorship tools under the procedures discussed in this article deprived research libraries and research institutions of needed materials on current events and cultural affairs. ${ }^{95}$ Ultimately, materials such as the London Economist and publications from the American Friends Service Committee (the Quakers) were confiscated, causing "considerable public criticism and embarrassment." In their article, Schwartz and Paul looked at the questionable legal bases for these confiscations and the resulting conflict with each citizen's First Amendment right to access to this type of material. ${ }^{97}$ They also offered possible legislative solutions and more acceptable restrictions. ${ }^{98}$ This article exemplifies an approach to legal scholarship developed throughout the twentieth century, notably at the Penn Law Review, wherein doctrinal analysis is enhanced, informed, and sometimes replaced by empirical data and a social science orientation.

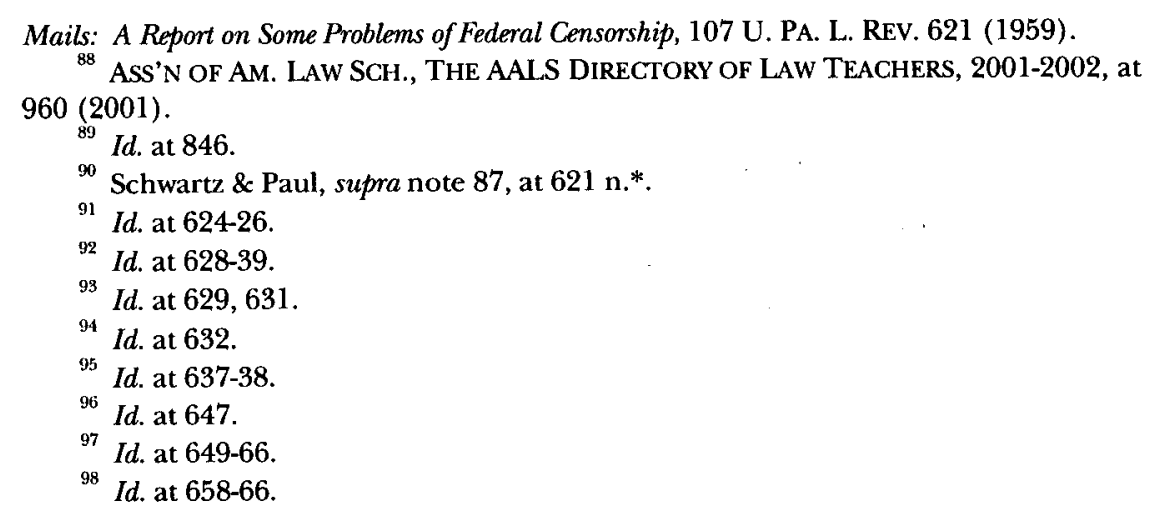


During the period following the Second World War, in addition to considering the legal issues confronting an expanding society, the Law Review published reflective articles examining legal education and the experience of faculty and students at Penn Law School. One example is an article published in the late 1960s authored by Herbert M. Silverberg, which looked at the beginnings of clinical legal education. $^{99}$

Silverberg's article detailed the operation of the Prison Research Council of the University of Pennsylvania Law School, which provided written responses to legal questions posed by prisoners. ${ }^{100}$ In his article, Silverberg questioned: (1) whether law students' research and counseling in response to prisoners' questions constitutes the 'practice of law'; ; 1 (2) whether it is fair for students to represent prisoners in trial courts rather than seasoned attorneys; ${ }^{102}$ and (3) whether it is preferable for law students to focus primarily on research and writing, tasks with which they have become familiar through their classroom experience, rather than representing clients in court. ${ }^{103}$ Silverberg highlights the benefits to students of participating in this type of clinical legal education: students sharpen their research and writing skills as well as their knowledge of substantive criminal law, gain some of the experiences of a practicing attorney, and serve a portion of society that has little access to legal services. ${ }^{104}$ For their part, prisoner-clients gained a better understanding of the functioning of the judicial system and of how they got where they were. ${ }^{105}$ Also, in rare instances, the work of the law students resulted in prisoners obtaining their freedom. ${ }^{106}$

Two Volume 118 articles published at the beginning of the $1970 \mathrm{~s}$ also focused on issues of the moment: school busing and the rights of students. Jack Greenberg, in an article that reprinted his speech from the 1970 Law Review banquet, looked at the social conflict in the United States "over whether this country will continue integrating its schools and its society, or halt and go backwards." ${ }^{\text {"107 }}$ Greenberg, who

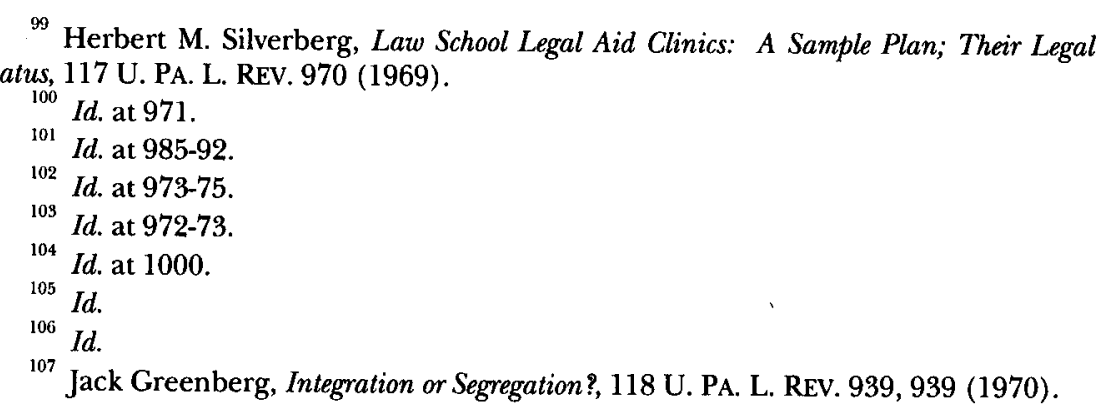


was director and counsel for the NAACP Legal Defense and Educational Fund at the time, ${ }^{108}$ attacked the political jargon of the day, which emphasized "social equality" rather than "educational equality"; $;^{109}$ the extreme negative characterization of busing to achieve the goal of integration in contrast to the general public acceptance of the busing of students to achieve other goals; ${ }^{110}$ and the misuse of the rhetoric of "community control."111 In his conclusion, Greenberg indicts the administration of President Richard Nixon, for while " $[\mathrm{t}]$ here is no clear statement of opposition to integration [,] . . . because that would be unacceptable[,] . . . [there is] deliberate confusion, slowdown on enforcement, and efforts to frighten the public."112 Greenberg ends on an optimistic note, finding the broader American public committed to educational integration and the courts and Congress to be an effective counterweight to the Nixon administration's backpedaling. ${ }^{113}$

In the same Volume, and commenting on the same period, Stephen Goldstein analyzed the increase in "students' 'rights." "114 Goldstein notes swings in the Court's deference to school administrators, finding that the early twentieth century was a period of "intense judicial scrutiny and skepticism of governmental action [which later] gave way to great judicial deference to administrative and other governmental decision-making." ${ }^{n 15}$ After the nation's experiences during the 1960s, law increasingly recognized students' rights to privacy and expression. ${ }^{116}$ Goldstein attributed these changing attitudes both to the increasingly collaborative (as opposed to didactic) philosophy of secondary and post-secondary education, ${ }^{117}$ and to a renewed judicial distrust of governmental action. ${ }^{118}$

${ }^{108}$ ASs'N OF AM. LAW SCH., supra note 88, at 545.

${ }^{109}$ Greenberg, supra note 107, at 940 .

${ }^{110} \mathrm{Id}$.

${ }^{111}$ Id. at 942.

112 Id. at 943

${ }^{113}$ Id.

${ }^{114}$ Stephen R. Goldstein, Reflections on Developing Trends in the Law of Student Rights, 118 U. PA. L. REV. 612, 612 (1970).

${ }^{115}$ Id. at 613 .

${ }^{116}$ See id. at 615-16 (noting "the adoption of ... more permissive rules concerning student expression" and "a growing recognition that students ... have rights of privacy that should not be unduly interfered with").

${ }^{117}$ See id. at 614-15 (describing a trend away from the "prescriptive" model and towards the "analytic" model in high schools and institutions of higher education).

${ }^{118}$ See id. at 617 (citing cases analyzing the "state law power of school boards" and striking down "school regulations restricting hair and dress choices of students and 
In Volume 118, the Law Review contained articles on racial discrimination and labor grievances, ${ }^{119}$ juvenile law, ${ }^{120}$ marches and protests, $^{121}$ and a California law restraining abortion. ${ }^{122}$ In addition to these articles, which show the Law Review's concern for and involvement with the major issues of the country during the 1960s and early 1970 s, the same Volume contained a tribute to a former University of Pennsylvania Law School Dean, Jefferson B. Fordham. ${ }^{123}$

Volume 125 of the Law Review, published in 1976 and 1977, featured an issue with a series of articles honoring William Henry Hastie. Hastie, who died in 1976, had been a Dean of Howard Law School, governor of the Virgin Islands, and a judge on the United States Court of Appeals for the Third Circuit. ${ }^{124}$ In the issue's lead essay, however, Louis H. Pollack, then-Dean of the Law School and later a member of the federal judiciary, stated:

[O]vershadowing all of these accomplishments was his partnership with Charles Houston and Thurgood Marshall in the most important lawyers' endeavor since the establishment of judicial review: developing the strategy and launching the litigation that, four years after Hastie was named to the Third Circuit, led to the overthrow of Plessy $v$. Ferguson. ${ }^{125}$

This Volume of the Law Review also dealt with such socially relevant topics as military justice, ${ }^{126}$ the statute that authorized the National School Lunch program, ${ }^{127}$ and the disproportionate impact theory of racial discrimination. ${ }^{128}$

their parents").

E.g., William B. Gould, Labor Arbitration of Grievances Involving Racial Discrimination, 118 U. PA. L. REV. 40 (1969).

${ }_{120}$ Comment, Statutory Vagueness in Juvenile Law: The Supreme Court and Mattiello v. Connecticut, 118 U. PA. L. REV. 143 (1969).

${ }^{121}$ Comment, The Constitutionality of a Requirement to Give Notice Before Marching, 118 U. PA. L. REV. 270 (1969).

${ }^{122}$ Jane Lang McGrew, Comment, To Be or Not to Be: The Constitutional Question of the Califormia Abortion Law, 118 U. PA. L. REV. 643 (1970).

Jefferson B. Fordham, 118 U. PA. L. REV. 665, 665-87 (1970) (comprising tributes to Dean Fordham by Chief Justice Earl Warren, Erwin N. Griswold, Paul W. Bruton, Bernard G. Segal, Louis H. Pollak, William B. Harvey, Terrance Sandalow, and Jerome J. Shestack).

${ }_{125}^{124}$ Louis H. Pollak, William Henry Hastie, 125 U. PA. L. REV. 1,1 (1976).

${ }^{125}$ Id. at $1-2$.

${ }^{126}$ Kent S. Bernard, Structures of American Military Justice, 125 U. PA. L. REv: 307 (1976)

${ }^{127}$ Comment, The National School Lunch Act: Statutory Difficulties and the Need for Mandatory Gradual Expansion of State Programs, 125 U. PA. L. REv. 415 (1976).

${ }_{128}$ Michael J. Perry, The Disproportionate Impact Theory of Racial Discrimination, 125

U. PA. L. REV. 540 (1976). 
At the end of the twentieth century, legal scholarship underwent dramatic changes. These major shifts were signaled by changes in the material published by the Penn Law Review. With the emergence of new interests in legal scholarship, such as law and economics, law and literature, feminist jurisprudence, law and society, and critical legal studies, law reviews began to receive and publish a large number of interdisciplinary articles. ${ }^{129}$ Rather than the earlier doctrinal articles and interests that had dominated American law reviews, interdisciplinary articles played an ever increasing role late in the century. ${ }^{130}$

For example, Volume 137, published in 1988 and 1989, touched on topics as wide-ranging as religious "shunning" and the Free Exercise Clause of the First Amendment, ${ }^{19 !}$ Article 9 of the Uniform Commercial Code in the context of certain elements of the philosophy of Ludwig Wittgenstein ${ }^{192}$ and the "abuse excuse" when an abused child kills her parent. ${ }^{133}$ This Volume also contained a symposium issue reflecting on the fiftieth anniversary of the adoption of the Federal Rules of Civil Procedure. ${ }^{134}$

In the 1990s, the Law Review published numerous articles dealing with sexuality and gender. In Volume 143, an article by David Cole addressed the broad issue of the social and legal construction of sexuality and examined the regulation of sexual expression in the Supreme Court's then-current jurisprudence. ${ }^{135}$ Cole charged that the Court, in this area, contradicted its own traditional First Amendment free speech doctrines. ${ }^{136}$ Cole underscores the relationship between

${ }^{129}$ See Posner supra note 8, at 1133 (noting the rise of "interdisciplinary, theoretical, [and] nondoctrinal" legal scholarship and the consequent impact on studentedited law reviews).

${ }^{130}$ See id. at 1133-34 (noting the end of a "Golden Age" of doctrinal legal scholarship between 1970 and 1990, and the rise of new forms of legal scholarship, particularly interdisciplinary forms).

${ }^{131}$ Justin K. Miller, Comment, Damned if You Do, Damned if You Don't: Religious Shunning and the Free Exercise Clause, 137 U. PA. L. REv. 271 (1988).

132 Dennis M. Patterson, Wittgenstein and the Code: A Theory of Good Faith Performance and Enforcement Under Article Nine, 137 U. PA. L. REV. 335 (1988).

${ }^{139}$ Joelle Anne Moreno, Comment, Killing Daddy: Developing a Self-Defense Strategy for the Abused Child, 137 U. PA. L. REV. 1281 (1989).

${ }^{134}$ Symposium, The 50th Anniversary of the Federal Rules of Civil Procedure, 1938-1988, 137 U. PA. L. REV. 1873 (1989).

${ }^{195}$ David Cole, Playing by Pornography's Rules: The Regulation of Sexual Expression, 143 U. PA. L. REV. 111 (1994).

${ }^{136}$ See id. at 176-77 (“[T] he regulation of sexual expression cannot be justified under traditional speech doctrines and indeed inverts two of the First Amendment's most fundamental principles," namely "the maxim that the First Amendment's central purpose is to protect public dialogue from official censorship, and the 'bedrock principle' 
public discourse on sexuality and governmental regulation of sexual expression, charging that the latter has "constructed a very particular type of sexuality, one in which transgressing lines and violating taboos is central to sexual excitement."

In the same issue, Lani Guinier, at the time a faculty member at Penn Law, tackled the topic of gender bias in legal education. Her article evidences the growing interest of the legal profession in using empirically based social science studies to examine legal topics. In this article, entitled Becoming Gentlemen, ${ }^{138}$ Guinier uses data from students at Penn Law, in the form of survey data, written narratives, and interview material. Based upon her survey of large numbers of students at the Law School, Guinier found that "the law school experience of women in the aggregate differ markedly from that of their male peers." ${ }^{139}$ Male and female graduates who had nearly identical entry-level academic qualifications nevertheless had law school experiences that diverged along gender lines. ${ }^{140}$

The female students in Guinier's study reacted very negatively to the Socratic method of classroom instruction and participated less frequently in classroom settings. ${ }^{141}$ Guinier determined that, for the female law students that she studied, "learning to think like a lawyer means learning to think and act like a man."

Social issues and interdisciplinary concerns were also evidenced in Volume 144, published in 1995 and 1996. That Volume contained articles dealing with the legal issues surrounding group homes for recovering substance abusers, ${ }^{143}$ religious freedom in the workplace, ${ }^{144}$ and First and Second Amendment issues occasioned by the rise of pri-

that society may not censor expression merely because it finds it offensive, morally or otherwise.").

${ }^{137}$ Cole, supra note 135 , at 177

${ }^{138}$ Lani Guinier et al., Becoming Gentlemen: Women's Experiences at One Iry League Law School, 143 U. PA. L. REV. 1 (1994).

139 Id. at 2.

${ }^{140}$ See id. at 3-4 ("Despite identical entry-level credentials, this performance differential between men and women is created in the first year of law school and maintained over the next three years.").

${ }^{141}$ Id.

142 Id. at 5.

${ }^{143}$ Laurie C. Malkin, Comment, Troubles at the Doorstep: The Fair Housing Amendments Act of 1988 and Group Homes for Recovering Substance Abusers, 144 U. PA. L. REV. 757 (1995).

${ }^{144}$ Sidney A. Rosenzweig, Comment, Restoring Religious Freedom to the Workplace: Title VII, RFRA and Religious Accommodation, 144 U. PA. L. REV. 2513 (1996). 
vate militias. ${ }^{145}$ This Volume also published an issue dedicated to a law and economics symposium entitled "Law, Economics, and Norms."146 From the very narrow and doctrinal focus of the American Law Register, the University of Pennsylvania Law Review has evolved into a home for legal scholarship in the most expansive sense of that term.

\section{BIBLIOMETRIC STUDIES}

After looking selectively at a sampling of the vast amount of legal scholarship published in the Law Review and its predecessor publications during the past 150 years, I next examine the impact that the University of Pennsylvania Law Review has had in the legal community. This can be determined, to a certain degree, by bibliometric studies, which look at citation counts to indicate the influence of articles that were published in the Law Review on subsequent legal scholarship and judicial opinions.

In the 2000 edition of the Journal Citation Reports published by the Institute for Scientific Information, we see one indicator of the Law Review's standing. The University of Pennsylvania Law Review was in the top ten law reviews nationally in terms of total number of scholarly citations received in the year 2000 in published law reviews. ${ }^{147}$ The Law Review ranked sixth, publishing thirty-eight articles in that year and receiving 1759 citations. $^{148}$ Other "top ten" law reviews include the Harvard Law Review, the Yale Law Joumal, the Columbia Law Review, the Stanford Law Review, the University of Chicago Law Review, the Michigan Law Review, the Virginia Law Review, and the California Law Review. ${ }^{149}$

Fred Shapiro's 1996 study of the most cited law review articles of "all time" lists the University of Pennsylvania Law Review as publishing four of the most cited articles. ${ }^{150}$ Other law reviews in this same range

${ }^{145}$ Joelle E. Polesky, Comment, The Rise of Private Militia: A First and Second Amendment Analysis of the Right to Organize and Right to Train, 144 U. PA. L. REV. 1593 (1996).

${ }^{146}$ Symposium, Law, Economics, E्ञ Norms, 144 U. PA. L. REv. 1643 (1996). (2001).

147 INST. FOR SCIENTIFIC INFO., JOURNAL CITATION REPORTS, at http://jcrweb.com

${ }^{148}$ Id. Importantly, this citation count excludes citations made to the American Law Register.

149.

${ }^{150}$ Fred R. Shapiro, The Most-Cited Law Review Articles Revisited, 71 CHI.-KENT L. REV. 751, 767-71 (1996) [hereinafter Shapiro, Most-Cited Revisited]; see also Fred R. Shapiro, The Most-Cited Law Review Articles, 73 CaL. L. REv. 1540, 1549 (1985). Shapiro's four articles from the Law Review were: Henry J. Friendly, "Some Kind of Hearing", 123 U. PA. L. REV. 1267 (1975) (\#55 on the list); Marvin E. Frankel, The Search for Truth: An 
of prominence include the law reviews from Harvard, Yale, Columbia, and Stanford, as well as the Joumal of Legal Studies (published by the University of Chicago Press). ${ }^{151}$ While citation-counting studies need to be viewed in context and with some caution, the work of the Institute for Scientific Information and Professor Shapiro demonstrate the preeminence of the University of Pennsylvania Law Review in the world of legal scholarship.

The impact of the Law Review is also shown by the fact that judges rely on articles from the Law Review as persuasive authority. In the McClintock study, the University of Pennsylvania Law Review was ranked sixth with a total of 732 citations by the Supreme Court, circuit courts of appeals, district courts, and state supreme courts for the time periods sampled. ${ }^{152}$ Isolating the citation patterns in U.S. Supreme Court opinions, the University of Pennsylvania Law Review ranked fourth, with 47 citations. $^{153}$ In the citation studies of both academic legal scholarship and of judicial opinions, the University of Pennsylvania Law Review is one of the most influential legal publications in the nation and reflects as well as contributes to the prominence of the Law School.

The empirical evaluations detailed above, then, demonstrate that the University of Pennsylvania Law Review has published articles that have positively influenced the development of legal scholarship as well as the administration of justice. The prominence of the Law Review in both the academic and judicial fields reflects positively on the institution of the University of Pennsylvania Law Review.

\section{PERSONALITIES}

Turning from the impact of the Law Review in the worlds of scholarship and applied law, this Essay next looks briefly on some of the personalities who have served as student editors of the University of Pennsylvania Law Review. In the mid-1960s, the Law Review's articu-

Umpireal View, 123 U. PA. L. REV. 1031 (1975) (\#76); Arthur Allen Leff, Unconscionability and the Code-The Emperor's New Clause, 115 U. PA. L. REV. 485 (1967) (\#86); Harold Leventhal, Environmental Decisionmaking and the Role of the Courts, 122 U. PA. L. REV. 509 (1974) (\#96). Shapiro, Most-Cited Revisited, supra, at 767-71.

${ }^{151}$ Shapiro, Most-Cited Revisited, supra note 150, at 763.

${ }^{152}$ Michael D. McClintock, The Declining Use of Legal Scholarship by Courts: An Empirical Study, 51 OKLA. L. REV. 659, 689 (1998).

${ }^{153}$ Id. at 691. In addition, the University of Pennsylvania Law Review was ranked fifth for total citations by the federal courts with 429 citations, fifth for total citations by U.S. courts of appeals with 234 citations, fourth for total citations by U.S. district courts with 148 citations, and tenth for total citations by state supreme courts with 303 citations. Id. at $690-94$. 
lated self-image was that of an organization similar to that of a large law firm:

The Law Review is basically structured like a large law firm. There are senior partners (the Board of Officers), junior partners (the Board of Editors), and associates (the second year students). Every member is impressed from the moment he enters the 'firm' that The Review demands excellence in analysis, research, and expression. Other students can struggle through a legal method paper or appellate advocacy brief and breathe a sigh of relief at its conclusion; when The Law Review member finishes one assignment he is simply given another... .

The work is demanding and not always exciting, but so is the legal profession. By undergoing this experience, The Law Review member can get a glimpse of what to expect in later years and a measure of his own dedication to the profession he has chosen for his life's work .... In any event ... when he leaves law school his experience will have made him more of a legal craftsman than the other members of his class. ${ }^{154}$

Serving on Law Review has an important influence on the careers of most student editors. Accomplishing the publication of a large and well respected legal publication with a demanding schedule enhances their legal education and sharpens their legal research and writing skills. In addition, the professional and social contacts that these students make last for a lifetime.

The benefit of service to the University of Pennsylvania Law Review can be seen in the careers of a few of those who served, starting with William Draper Lewis. Lewis, who received his LL.B. from the Law School in 1891, was editor of the American Law Register from 1892 to 1896 and went on to become Dean of the Law School. ${ }^{155}$

The board of editors for Volume 75 of the Law Review included Philip Werner Amram as editor-in-chief and Sadie M. Alexander as an associate editor. ${ }^{156}$ Amram was the first Jewish editor-in-chief. ${ }^{157} \mathrm{He}$ later joined the Law School faculty along with his father, David Werner Amram, and was an editor of the well known Pennsylvania practice publication, Goodrich-Amram Pennsylvania Procedural Rules. ${ }^{158}$ Sadie M. Alexander, who received an LL.B. in 1927, was the University of Pennsylvania Law School's first black woman graduate. ${ }^{159}$ She also "earned her Ph.D. in economics from Penn-the first black woman in

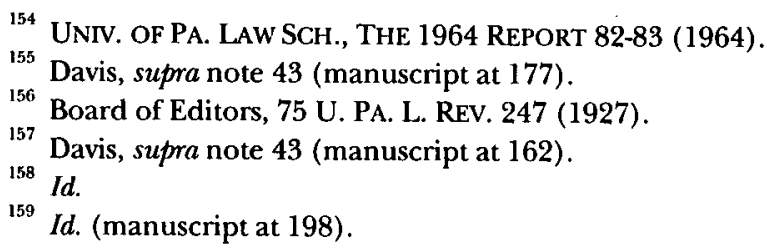


the country to earn a Ph.D. in any subject." ${ }^{160}$

In mid-century, Arlin M. Adams served as editor-in-chief for Volume 94, published in 1945 and $1946 .{ }^{161}$ Adams served as Pennsylvania secretary of public welfare from 1963 to 1969 and as a judge of the United States Court of Appeals for the Third Circuit from 1969 to 1987. ${ }^{162}$ He has taught as a lecturer at the Law School, and his legal research focuses on religion and the First Amendment. ${ }^{163}$

Curtis R. Reitz, currently the Algernon Sidney Biddle Professor at Penn Law School, was editor-in-chief for Volume $104 ;{ }^{164}$ Dolores Korman Sloviter was one of the notes editors for the same Volume. ${ }^{165}$ Sloviter was one of eight women in a class of $132 .{ }^{166}$ She was the first woman appointed to the Third Circuit Court of Appeals and served as Chief Judge from 1991 to $1998 .{ }^{167}$ "Of her almost 700 published opinions, among the most significant was a 1996 decision declaring the portion of the Communications Decency Act restricting certain communications over computer networks to be in violation of the First Amendment, a decision affirmed by the U.S. Supreme Court."168 Another colleague of Reitz and Sloviter on this Volume of the Law Review was Peter Liacouras. ${ }^{169}$ Liacouras later became Dean of Temple University School of Law from 1972 to 1982 and then President of Temple University from 1982 to $2000 .^{170}$ These are just a few select examples of the career paths of Penn Law Review editors. Appendix A of this Essay provides a complete list of the editors-in-chief of the Law Review over the past 100 years. Appendix B lists the editors of the American Law Register from 1852 to 1895.

\section{CONCLUSION}

Born out of the late-nineteenth-century reform of legal education to become an icon of legal scholarship at the University of Pennsylva-

${ }^{160} \mathrm{Id}$.

${ }^{161}$ Id. (manuscript at 190).

${ }^{162} I d$.

${ }^{163} \mathrm{Id}$.

${ }^{164}$ Id. (manuscript at 186); Board of Editors, 104 U. PA. L. REV. 954 (1945-1946).

${ }^{165}$ Board of Editors, 104 U. PA. L. REv. 954 (1955-1956).

${ }^{166}$ Davis, supra note 43 (manuscript at 204).

${ }^{167}$ Id.

${ }^{168}$ Id. (referring to $A C L U$ v. Reno, 929 F. Supp. 824 (1996), affd, 521 U.S. 844 (1997)).

${ }^{169}$ Board of Editors, 104 U. PA. L. REV. 507 (1955-1956).

${ }^{170}$ Davis, supra note 43 (manuscript at 196). 
nia Law School and in the worlds of legal scholarship and legal practice, today the Law Review looks forward to the future. The Law Review has led many trends in legal scholarship over the past century and a half, from legal realism to critical legal studies and the law and economics movement. The Law Review has offered itself as a forum for legal scholars to advance and to test new ideas in the broader legal community. The discourse contained in the Law Review has had a strong impact on legal scholarship and judicial decision making, as indicated by the patterns of citations. Student editors of the Law Review have graduated from the University of Pennsylvania Law School to take up major academic, law firm, judicial, and governmental positions. Today, along with a financially sound and well-respected paper legal publication, the University of Pennsylvania Law Review boasts an elegant presence on the Internet. ${ }^{171}$ The Law Review looks back proudly over 150 years of preeminence as a major legal publication and anticipates its next sesquicentury.

${ }^{171}$ University of Pennsylvania Law Review, at http://www.law.upenn.edu/ journals/lrev (last visited May 12, 2002). 


\section{APPENDIX A: STUDENT EDITORS-IN-CHIEF OF THE AMERICAN LAW REGISTER AND THE UNIVERSITY OF PENNSYLVANIA LAW REVIEW, 1896-2002}

\begin{tabular}{|c|c|c|}
\hline Volume 44 & 1896 & $\begin{array}{l}\text { Thomas James Meagher, Walter } \\
\text { Cazenove Douglas, Jr. }\end{array}$ \\
\hline Volume 45 & 1897 & $\begin{array}{l}\text { Walter Cazenove Douglas, Jr., Roy } \\
\text { Wilson White }\end{array}$ \\
\hline Volume 46 & 1898 & Roy Wilson White, Arthur E. Weil \\
\hline Volume 47 & 1899 & $\begin{array}{l}\text { Arthur E. Weil, Thomas Cahall, Paul } \\
\text { V. Connolly }\end{array}$ \\
\hline Volume 48 & 1900 & Paul V. Connolly, E. Wilbur Kriebel \\
\hline Volume 49 & 1901 & $\begin{array}{l}\text { E. Wilbur Kriebel, Theodore J. } \\
\text { Grayson }\end{array}$ \\
\hline Volume 50 & 1902 & Thornton M. Pratt \\
\hline Volume 51 & 1903 & John Glass Kaufman \\
\hline Volume 52 & 1904 & Edgar Howard Boles \\
\hline Volume 53 & 1905 & Francis H. Shields \\
\hline Volume 54 & 1906 & Otto Wolff, Jr. \\
\hline Volume 55 & 1907 & T. Walter Gilkyson \\
\hline Volume 56 & 1908 & Paul Freeman \\
\hline Volume 57 & 1908-1909 & Russell S. Wolfe \\
\hline Volume 58 & $1909-1910$ & Shippen Lewis \\
\hline Volume 59 & 1910-1911 & Shippen Lewis, Ralph J. Baker \\
\hline Volume 60 & 1911-1912 & Ralph J. Baker, William A. Schnader \\
\hline Volume 61 & $1912-1913$ & Samuel Rosenbaum \\
\hline Volume 62 & $1913-1914$ & Douglass D. Storey \\
\hline Volume 63 & $1914-1915$ & Edward W. Madeira \\
\hline Volume 64 & $1915-1916$ & Lemuel Braddock Schofield \\
\hline Volume 65 & $1916-1917$ & Raymond K. Denworth \\
\hline Volume 66 & $1917-1918$ & $\begin{array}{l}\text { Thomas K. Finletter, Henry H. } \\
\text { Houck (acting editor-in-chief) }\end{array}$ \\
\hline Volume 67 & 1918-1919 & David Werner Amram \\
\hline Volume 68 & $1919-1920$ & Thomas K. Finletter \\
\hline Volume 69 & $1920-1921$ & Francis H. Bohlen, Jr. \\
\hline Volume 70 & 1921-1922 & A. Carson Simpson \\
\hline Volume 71 & 1922-1923 & Cadmus Z. Gordon, Jr. \\
\hline Volume 72 & 1923-1924 & Philip Wallis \\
\hline
\end{tabular}




\begin{tabular}{|c|c|c|}
\hline Volume 107 & 1958-1959 & David R. Tomb, Jr. \\
\hline Volume 108 & $1959-1960$ & Anthony G. Amsterdam \\
\hline Volume 109 & $1960-1961$ & Bruce B. Wilson \\
\hline Volume 110 & 1961-1962 & David W. Miller, James D. Crawford \\
\hline Volume 111 & 1962-1963 & David H. Marion \\
\hline Volume 112 & 1963-1964 & Dennis M. Flannery \\
\hline Volume 113 & 1964-1965 & Stephen M. Goodman \\
\hline Volume 114 & $1965-1966$ & James Eiseman, Jr. \\
\hline Volume 115 & 1966-1967 & Timothy N. Black \\
\hline Volume 116 & 1967-1968 & Peter S. Greenberg \\
\hline Volume 117 & 1968-1969 & Loftus E. Becker, Jr. \\
\hline Volume 118 & $1969-1970$ & I. Michael Greenberger \\
\hline Volume 119 & $1970-1971$ & William F. Sheehan, III \\
\hline Volume 120 & 1971-1972 & Jordan Luke \\
\hline Volume 121 & $1972-1973$ & John H. Mason \\
\hline Volume 122 & $1973-1974$ & Jonathan Z. Cannon \\
\hline Volume 123 & $1974-1975$ & M. Duncan Grant \\
\hline Volume 124 & 1975-1976 & Nancy J. Bregstein \\
\hline Volume 125 & $1976-1977$ & Gary L. Sasso \\
\hline Volume 126 & $1977-1978$ & Alfred W. Putnam, Jr. \\
\hline Volume 127 & $1978-1979$ & Pamela Daley Kendrick \\
\hline Volume 128 & $1979-1980$ & Kit Kinports \\
\hline Volume 129 & $1980-1981$ & Marcie R. Horowitz \\
\hline Volume 130 & 1981-1982 & Dale Louise Moore \\
\hline Volume 131 & $1982-1983$ & Natalie Wexler \\
\hline Volume 132 & 1983-1984 & Sean P. Wajert \\
\hline Volume 133 & $1984-1985$ & R. Charles Miller \\
\hline Volume 134 & $1985-1986$ & Michael P. Doss \\
\hline Volume 135 & $1986-1987$ & Vernon L. Francis \\
\hline Volume 136 & $1987-1988$ & Marci A. Hamilton \\
\hline Volume 137 & 1988-1989 & William Bennett Petersen \\
\hline Volume 138 & $1989-1990$ & Peter Nicholas Flocos \\
\hline Volume 139 & $1990-1991$ & Alexander C. Gavis \\
\hline Volume 140 & 1991-1992 & William Scott Biel \\
\hline Volume 141 & $1992-1993$ & M. Mazen Anbari \\
\hline Volume 142 & 1993-1994 & Megan L. Jacobson \\
\hline Volume 143 & 1994-1995 & Edward J. Normand \\
\hline Volume 144 & 1995-1996 & Katherine A. Kelly \\
\hline Volume 145 & $1996-1997$ & Peter D. Blumberg \\
\hline
\end{tabular}




\begin{tabular}{|c|c|c|}
\hline Volume 73 & $1924-1925$ & Harris C. Arnold \\
\hline Volume 74 & $1925-1926$ & W. James MacIntosh \\
\hline Volume 75 & $1926-1927$ & Philip Werner Amram \\
\hline Volume 76 & $1927-1928$ & David H. Frantz \\
\hline Volume 77 & 1928-1929 & Robert Brigham \\
\hline Volume 78 & $1929-1930$ & Carroll R. Wetzel \\
\hline Volume 79 & 1930-1931 & Knox Henderson \\
\hline Volume 80 & 1931-1932 & John C. Bruton, Jr. \\
\hline Volume 81 & $1932-1933$ & W. Wilson White \\
\hline Volume 82 & 1933-1934 & Howard S. McMorris \\
\hline Volume 83 & $1934-1935$ & Harry E. Sprogell \\
\hline Volume 84 & 1935-1936 & Bernard V. Lentz \\
\hline Volume 85 & $1936-1937$ & Victor J. Roberts \\
\hline Volume 86 & 1937-1938 & James A. Sutton \\
\hline Volume 87 & 1938-1939 & Thomas P. Glassmoyer \\
\hline Volume 88 & $1939-1940$ & Theodore O. Rogers \\
\hline Volume 89 & $1940-1941$ & Lipman Redman \\
\hline Volume 90 & 1941-1942 & Joseph W. Swain, Jr. \\
\hline Volume 91 & $1942-1943$ & $\begin{array}{l}\text { William B. Johnson, Robert M. Landis, } \\
\text { Bart E. Ferst }\end{array}$ \\
\hline Volume 92 & $1943-1944$ & $\begin{array}{l}\text { Bart E. Ferst, Frederick G. } \\
\text { Kempin, Jr. }\end{array}$ \\
\hline Volume 93 & $1944-1945$ & John R. Miller \\
\hline Volume 94 & $1945-1946$ & John R. Miller, Arlin M. Adams \\
\hline Volume 95 & $1946-1947$ & $\begin{array}{l}\text { Arlin M. Adams, Raymond J. Bradley, } \\
\text { Leon Ehrlich }\end{array}$ \\
\hline Volume 96 & $1947-1948$ & $\begin{array}{l}\text { Raymond. J. Bradley, John F. Zeller, } \\
\text { III, Noyes E. Leech }\end{array}$ \\
\hline Volume 97 & 1948-1949 & $\begin{array}{l}\text { William D. Valente, Robert W. } \\
\text { Valimont }\end{array}$ \\
\hline Volume 98 & $1949-1950$ & Charles C. Hileman, III \\
\hline Volume 99 & $1950-1951$ & James C.N. Paul \\
\hline Volume 100 & $1951-1952$ & Joseph P. Flanagan, Jr. \\
\hline Volume 101 & $1952-1953$ & Ellis H. McKay \\
\hline Volume 102 & $1953-1954$ & Bruce L. Castor \\
\hline Volume 103 & $1954-1955$ & Joseph V. Reaph, Jr. \\
\hline Volume 104 & $1955-1956$ & Curtis R. Reitz \\
\hline Volume 105 & $1956-1957$ & Ronald P. Wertheim \\
\hline Volume 106 & $1957-1958$ & John G. Harkins, Jr. \\
\hline
\end{tabular}


Volume $146 \quad$ 1997-1998 Clifford Ruprecht

Volume 147 1998-1999 John J. Butts

Volume $148 \quad$ 1999-2000 Daniel R. Garodnick

Volume 149 2000-2001 Kedric L. Payne

Volume 150 2001-2002 Michael A. Mugmon

Volume 151 2002-2003 Dena Greenspan 
APPENDIX B: EDITORS OF THE AMERICAN LAW REGISTER, $1852-1895^{172}$

\begin{tabular}{|c|c|c|}
\hline Volumes 1-9 & $1852-1860$ & Asa I. Fish, Henry Wharton \\
\hline Volume 10 & 1861 & $\begin{array}{l}\text { Hon. Isaac F. Redfield, Prof. } \\
\text { Theodore W. Dwight, Prof. Amos } \\
\text { Dean, Henry Wharton }\end{array}$ \\
\hline Volume 11 & 1862 & $\begin{array}{l}\text { Hon. Isaac F. Redfield, Prof. } \\
\text { Theodore W. Dwight, Prof. Amos } \\
\text { Dean, Henry } \\
\text { Mitchell }\end{array}$ \\
\hline Volumes 12-13 & $1863-1864$ & $\begin{array}{l}\text { Hon. Isaac F. Redfield, Prof. } \\
\text { Theodore W. Dwight, Prof. Amos } \\
\text { Dean, Hon. J.F. Dillon, John A. } \\
\text { Jameson, James T. Mitchell }\end{array}$ \\
\hline Volumes $14-17$ & $1865-1869$ & $\begin{array}{l}\text { James T. Mitchell, Hon. Isaac F, } \\
\text { Redfield, Prof. Theodore W. Dwight, } \\
\text { Prof. Amos Dean, Hon. J.F. Dillon, } \\
\text { John A. Jameson, Alex Martin }\end{array}$ \\
\hline Volume 18 & 1870 & $\begin{array}{l}\text { James T. Mitchell, Hon. Isaac F. } \\
\text { Redfield, Hon. Edmund H. Bennett, } \\
\text { Prof. Theodore W. Dwight, Hon. J.F. } \\
\text { Dillon, Alex Martin }\end{array}$ \\
\hline Volume 19 & 1871 & $\begin{array}{l}\text { James T. Mitchell, Hon. Isaac F. } \\
\text { Redfield, Hon. Edmund H. Bennett, } \\
\text { Prof. Theodore W. Dwight, Hon. J.F. } \\
\text { Dillon, Hon. John A. Jameson, Alex } \\
\text { Martin }\end{array}$ \\
\hline Volume 20 & 1872 & $\begin{array}{l}\text { James T. Mitchell, Hon. Isaac F. } \\
\text { Redfield, Hon. Edmund H. Bennett, } \\
\text { Prof. Theodore W. Dwight, Hon. J.F. } \\
\text { Dillon, Alex Martin }\end{array}$ \\
\hline
\end{tabular}


Volumes 21-22 $\quad 1873-1874$

Volumes 23-24 1875-1876

Volumes 25-26 . 1877-1878

Volumes 27-28 1879-1880

Volume 29

1881

Volumes 30-34 1882-1886

Volume 35

1887

Volume 36

1888

Volume 37
Hon. James T. Mitchell, Hon. Isaac

F. Redfield, Hon: Edmund $\mathbf{H}$.

Bennett, Prof. Theodore W. Dwight, Hon. J.F. Dillon, Hon. John A. Jameson, Alex Martin, Henry G. Atwater

Hon. James T. Mitchell, Hon. Isaac F. Redfield, Hon. Edmund $\mathrm{H}$. Bennett, Prof. Theodore W. Dwight, Hon. J.F. Dillon, Hon. Charles H. Wood, Alex Martin, Henry G. Atwater

Hon. James T. Mitchell, Hon. Edmund H. Bennett, Prof. Theodore W. Dwight, Hon. J.F. Dillon, Hon. T.M. Cooley, Hon. Charles H. Wood, A. Sydney Biddle

Hon. James T. Mitchell, Hon. Edmund H. Bennett, Hon. J.F. Dillon, Hon. T.M. Cooley, Hon. Charles H. Wood

Hon. James T. Mitchell, Hon. Edmund H. Bennett, Hon. T.M. Cooley, Hon. Charles H. Wood

Hon. James T. Mitchell, Hon. Edmund H. Bennett, Hon. Eli S. Hammond, Hon. T.M. Cooley, Hon. Charles H. Wood, Frank P. Prichard Frank P. Prichard, Hon. Edmund $\mathrm{H}$. Bennett, Hon. Eli S. Hammond, Prof. H. Wade Rogers, Henry Budd, Hon. T.M. Cooley, Hon. Chas. H. Wood, Hon. Marshall S. Ewell

Hon. T.M. Cooley, Hon. E.S. Hammond, Hon. E.H. Bennett, Hon. Chas. H. Wood, Prof. H. Wade Rogers, Prof. M.D. Ewell, Henry Budd, J.C. Sellers, John B. Uhle Hon. T.M. Cooley, James C. Sellers, 
[Vol. 150: 1875

\begin{tabular}{|c|c|c|c|c|}
\hline & & John B. Uhle & & \\
\hline Volume 38 & $1890^{173}$ & John Bethell Uhle & & \\
\hline Volumes $40-41$ & $1892-1893$ & $\begin{array}{l}\text { George Wharton } \\
\text { Draper Lewis }\end{array}$ & Pepper, & William \\
\hline blumes $42-43$ & 1894-1895 & $\begin{array}{l}\text { George Wharton } \\
\text { Draper Lewis, Will }\end{array}$ & $\begin{array}{l}\text { Pepper } \\
\text { Iam Stru }\end{array}$ & $\begin{array}{l}\text { Villiam } \\
\text { s Ellis }\end{array}$ \\
\hline
\end{tabular}

${ }^{173}$ Volume 39, the 1891 volume of the American Law Register, does not include a list of editors. A note in that Volume indicates that the commercial publisher of the American Law Register, D.B. Canfield Company, experienced financial difficulties, and, as a result, the periodical ceased publication, and the copyright and subscribers list was turned over to the University of Pennsylvania Press. Publisher's Note, 39 AM. L. REG. 448 (1891). 